\title{
STRIKES AND POWER IN BRITAIN, $1870-1920^{*}$
}

Not long ago, sociologists and labor economists used to talk confidently about the "natural history of the strike". By that they meant its rather smooth progress along a line that supposedly rose rapidly in the early stages of industrial growth, gradually flattened out with the establishment of stable collective bargaining, and slowly fell as the strike proceeded to "wither away" in the prosperity of "advanced industrial society".

Such notions have much less currency today. Striking has not died out, industrial conflict continues at high levels and periodically erupts into massive confrontations. Newer scholarship, informed by different concerns and predilections, has little sympathy with the earlier work, and has moved in quite different directions. The historical analysis of strikes has been thoroughly transformed, and bears little resemblance to the older studies. The emphasis now is upon complexity and variation, and teleological concepts about long-term trends have been replaced by a much finer sense

* This essay stems from a continuing research project on strikes in Britain. The first stage of the project involved a quantitative analysis of long-term strike patterns and was published as Industrial Conflict in Modern Britain (London, 1979). The second, and still ongoing, stage involves an attempt to refine and illustrate the argument first adumbrated in Industrial Conflict in Modern Britain through a more detailed study of strikes in the late nineteenth and early twentieth centuries. The first fruits of this effort appeared as "Strikes, 1870-1914", in: A History of British Industrial Relations 1875-1914, ed. by Ch. Wrigley (Brighton, 1982). The analysis was extended and put into a more comparative perspective for presentation to the 1981 Tutzing conference on the development of trade unionism in Europe. This appeared as "Strikes and the Struggle for Union Organization: Britain and Europe", in: The Development of Trade Unionism in Great Britain and Germany, 1880-1914, ed. by W. J. Mommsen and H.-G. Husung (London, 1985). Subsequently, I have had the opportunity to re-focus the argument upon Britain in papers for the conference on comparative strike movements at the Maison des Sciences de l'Homme in June 1982, and for the Anglo-Dutch Labour Conference in 1984. The present essay stems from the latter meeting; a longer, and presumably definitive, treatment will appear with other papers from the Paris conference in a volume to be edited by Leopold Haimson and Charles Tilly for Cambridge University Press. 
of the contingent nature of strikes and labor movements. Inevitably, there has been a greater attention to local detail, to individual strikes or movements within regions or industries. The strike is coming to be understood in terms of specific social contexts and as a manifestation of relations between workers, employers and, in many instances, the state rather than as some unproblematic reflection of working-class interests and grievances.

No doubt the sum of this new work is a major advance in the understanding of strikes and of labor history more broadly. But it does seem that something has been lost in the excessively local orientation of research, and in the decomposition and disaggregation of overall strike indices. That is the way in which strikes feed upon each other and turn from single conflicts into strike movements with a momentum of their own. This omission is particularly obvious in the British experience, where the case-study of the individual strike or the particular factory has left largely unexplored the forces that have produced strike waves, those occasional outbursts of militancy which so mark the history of industrial relations. ${ }^{1}$

So, while not wishing to argue for a return to "the natural history of the strike", I would like to urge the value of an analysis of the trends in strikes across British society. ${ }^{2}$ There are, of course, problems with such aggregatelevel analysis, of which we are all aware. Aggregate data can tell us little about the dynamics of strike movements or the mode of transmission from one industry to another, but they can at the least inform us of when strike movements occurred, of their dimensions and locations, and their interrelation with other key variables. That alone would seem a useful service. In this particular essay, however, the aim is to go a bit further and to attempt to cast some light upon four specific issues.

First, by combining the rather fragmentary evidence on strikes for the years $1870-90$ with the much fuller information available in official statistics for the period following, it should be possible to refine existing notions regarding the transition from older to newer patterns of collective action. ${ }^{3}$ More precisely, it will be argued that the changes that occurred in styles of mobilization were extremely uneven, that they do not fit into any neat dichotomy of traditional versus modern, and that the strike itself does not

1 E. J. Hobsbawm, "Economic Fluctuations and Some Social Movements since 1800", in Labouring Men (London, 1964); F. Boll, "International Strike Waves: A Critical Assessment", in: The Development of Trade Unionism.

${ }^{2}$ For a useful review under that very rubric, see E. W. Evans and S. W. Creigh, "The Natural History of the Strike in Britain", in: Labour History, No 39 (1980).

${ }^{3}$ On the quality of UK strike statistics and the methods involved in gathering classifying them, see K. Knowles, Strikes (Oxford, 1952); S. W. Creigh, "The Origins of British Strike Statistics", in: Business History, XXIV (1982). 
seem to have played a major role in working people's "repertoire of contention" until after 1867.

The second point that will be stressed is the importance of strike waves to the British record of industrial conflict and the linkages that seem to have existed between these periodic explosions of militancy and short- and longterm economic trends. The third argument qualifies this second point, for it will be suggested that, beneath the considerable variation over time in the incidence and scale of strikes, there was a fundamental continuity to strike movements before 1914. What united these several outbursts of conflict was a broad effort to enrol ever larger sections of the workforce into stable unions. This de facto objective seems, in retrospect, to have overshadowed issues of wages, hours, working conditions or job control, however important these may have been in individual situations.

Finally, the paper will conclude with a quick look beyond 1914 to the war and the post-war unrest. Based upon this, it will be argued that a major discontinuity entered the history of strikes and labor relations with the period of war. Somehow the war brought about a distinct widening of the aims of labor beyond the establishment of organization, and imparted a more agressive and insurgent quality to working people's industrial and political activities. It was this new dimension to unrest, this new thrust for power that lay behind it, that made the post-war confrontation so deep and protracted. Though the details of this critical moment in the history of British industrial conflict are beyond the scope of this paper, the events of 1917-20 nonetheless constitute the terminus for the evolution sketched out here and, in this way, form an integral part of the empirical groundings for the analysis. ${ }^{4}$

\section{II}

"Striking has become a disease, and a very grave disease, in the body social", intoned George Phillips Bevan at the beginning of his learned lecture on strikes to the Royal Statistical Society on 20 January 1880 . Worse still, the disease "as yet shows no sign of having run its course", and the concerned statistician could not bring himself "to believe in any speedy cure", whether "by legislative measures or any one course of action". Bevan's subject was the record of industrial disputes during the 1870's, which he compiled in a most thorough and useful fashion, and his judgment on this particular era in industrial relations was endorsed by the labor leader

4 For some of the detail, see my "Coping with Labour, 1918-1926", in: Social Conflict and the Political Order in Modern Britain, ed. by J. E. Cronin and J. Schneer (New Brunswick, 1982). 
George Howell, who also had recourse to the metaphor from pathology. "This was a period of strike epidemics, not to occur again, let us hope", wrote Howell on the very eve of the next such epidemic in $1889 .{ }^{5}$

The figures produced by Bevan, and reproduced as part of Table 1, are indeed impressive; impressive enough to suggest that the early 1870 's probably were the years when strikes became the dominant form of workers' collective activity. Thus, though the labor market was buoyant in 1870 - unemployment was only 3.9 per cent, compared with 7.9 per cent in 1868 and 6.7 per cent in 1869 - only thirty strikes were recorded. The figure tripled in 1871, to 98 , and more than that again in 1872, when 343 disputes were noted (see also graph). The levels remained high the 1870's, as what Thomas Wright called "the alternation between 'flushes' and 'crashes" shifted the balance of tactical advantage back and forth, and so prompted first workers and then employers to press their advantage to the fullest. ${ }^{6}$ Indeed, the strike wave of the early 1870 's was probably the first of those major explosions of militancy and union organization that have characterized much of the subsequent history of British industrial relations. Like the later waves of 1889-90, 1911-13 and 1919-20, it represented not merely an escalation of overt conflict between workers and employers, but also a shift towards the more inclusive organization of less skilled workers, together with an upsurge of rank-and-file activism, a rejection of the cautious advice of established officials, and a renewed emphasis upon the efficacy of strike activity. ${ }^{7}$ Like later insurgencies, too, it was followed by a

${ }^{5}$ G. Ph. Bevan, "The Strikes of the Past Ten Years", in: Journal of the Royal Statistical Society, XLIII (1880); G. Howell, “Great Strikes: Their Origin, Costs, and Results”, in: Co-operative Wholesale Societies, Annual for 1889, p. 310.

${ }^{6}$ Th. Wright, "On the Condition of the Working Classes", in: Fraser's Magazine, New Series, IV (1871), p. 427.

7 One implication of this recurring pattern is that the tension between entrenched union leaders and rank-and-file activists is a long-term, indeed structural, aspect of labor history, not peculiar to any particular moment, but to those various periods when workers on the shop-floor perceive a possibility of advance beyond what the leaders have come to expect. Ideological factors, generational differences, degrees of bureaucratization, and government policy all help to condition and mediate this tension, but its roots seem to me to go much deeper. The evidence for this view is scattered widely throughout the record of labor history, but one might begin the study of the unofficial character of virtually all insurgencies with George Howell. He claimed in 1890 that "It is perhaps a bold thing to say, but the statement can be made with considerable confidence, that in ninety per cent. of the strikes which take place, the men directly concerned are the instigators and promoters, and that the union is the brake on the wheel which prevents too great precipitation, and liability to consequent failure." See G. Howell, The Conflicts of Capital and Labour, 2nd ed. (London, 1890), p. 211, for the specific instance; and, for a more general argument to this effect, Ch. Sabel, "The Internal Politics of Trade Unions", in: Organizing Interests in Western Europe, ed. by S. Berger (Cambridge, 1981). 
Table 1. Strikes and strikers in Britain, 1870-1914

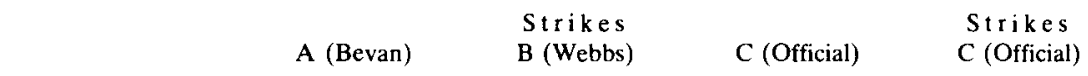

$\begin{array}{rrr}1870 & 30 & \\ 71 & 98 & \\ 72 & 343 & \\ 73 & 365 & \\ 74 & 286 & \\ 75 & 245 & 17 \\ 76 & 229 & 23 \\ 77 & 180 & 38 \\ 78 & 268 & 72 \\ 79 & 308 & 46 \\ 1880 & & 20 \\ 81 & & 14 \\ 82 & & 26 \\ 83 & & 31 \\ 84 & & 20 \\ 85 & & 24 \\ 86 & & 27 \\ 87 & & 37 \\ 88 & & 111 \\ 89 & & \end{array}$

$\begin{array}{rr}517 & 119,000 \\ 1,211 & 337,000 \\ 1,040 & 393,000 \\ 906 & 267,000 \\ 700 & 357,000 \\ 782 & 599,000 \\ 929 & 257,000 \\ 745 & 207,000 \\ 926 & 148,000 \\ 864 & 167,000 \\ 711 & 201,000 \\ 719 & 138,000 \\ 648 & 135,000 \\ 642 & 111,000 \\ 442 & 117,000 \\ 387 & 94,000 \\ 354 & 56,000 \\ 358 & 68,000 \\ 486 & 158,000 \\ 601 & 101,000 \\ 399 & 224,000 \\ 436 & 170,000 \\ 531 & 385,000 \\ 903 & 831,000 \\ 857 & 1,233,000 \\ 1,497 & 516,000 \\ 972 & 326,000\end{array}$

Sources: Bevan, "The Strikes of the Past Ten Years", loc. cit., p. 37 (derived from various newpapers and reports); S. and B. Webb, The History of Trade Unionism (New York, 1920), p. 347, note (collected from strikes mentioned in The Times); Board of Trade, Reports on Strikes and Lockouts, 1888-1914. 
Strikes and union organization, 1870-1914

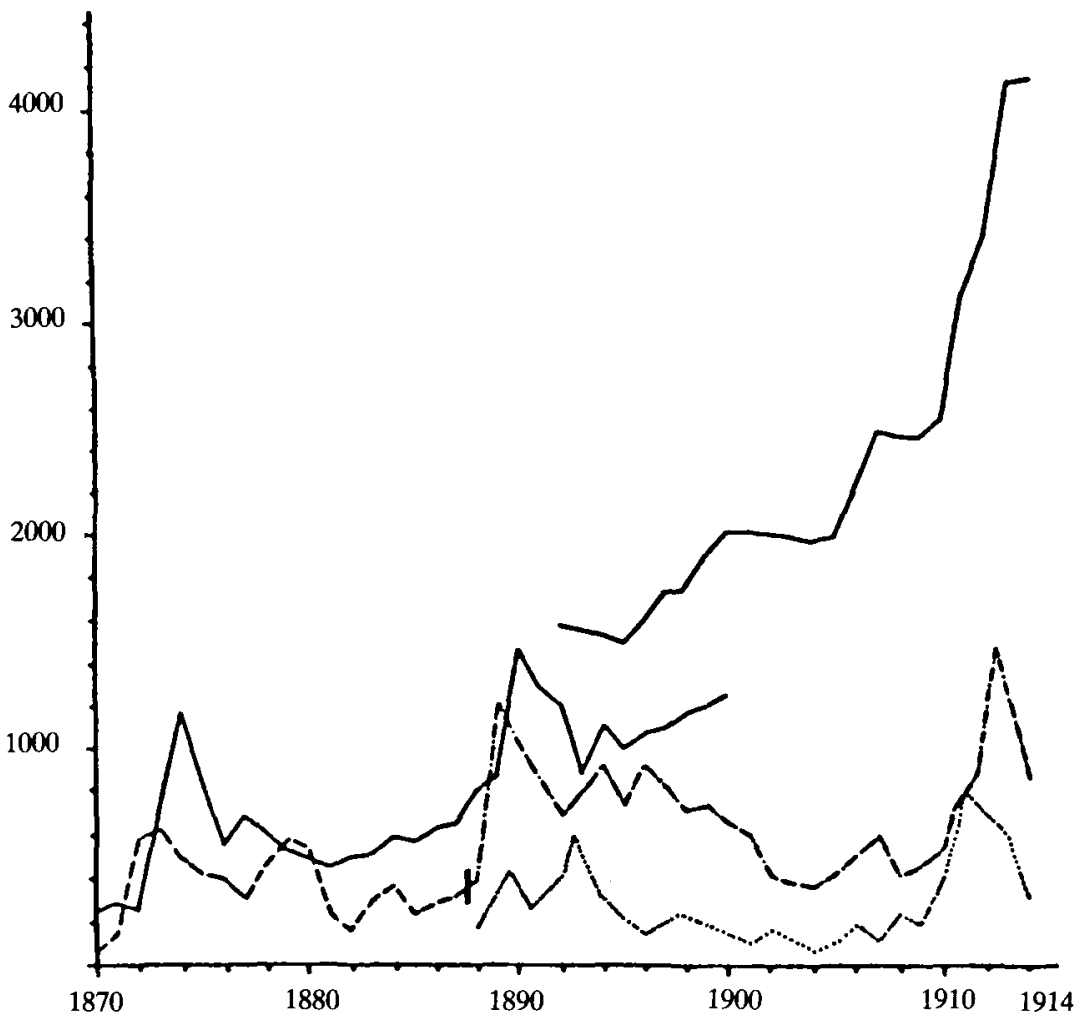

\footnotetext{
Number of strikes (estimated)

-... Number of strikes

-...... Number of strikers (in thousands)

Number of trade unionists (in thousands)
}

The graphs of the number of strikes and of strikers since 1888 are based upon the data presented in Table 1 . The estimates of the level of strike activity for the years before 1888 have been derived by combining data from Bevan and from the Webbs with the published reports of the Board of Trade. These are only very rough estimates arrived at by extrapolating backwards from the post-1888 Board of Trade data to the earlier years using the ratios between the three sets of figures for periods of overlap. They are probably reasonably reliable for the direction and magnitude of annual fluctuations, but the general levels may be somewhat distorted by the necessary reliance upon the Webb's narrow sample. Still, the results tally with other, more impressionistic, sorts of evidence. The earlier and lower totals refer to the membership of TUC-affiliated unions, the later and higher ones to total trade-union membership. 
substantial counter-attack by employers, which succeeded in beating back workers' organization from its furtherst and weakest extensions, but which did not manage to turn the clock back to the state of organization or the lower level of strikes that had existed prior to the strike wave. The modes used to re-establish order within "the industrial relations system" also exhibited marked similarity during these successive counter-offensives: an odd mix of employer attempts to inflict symbolic defeats upon key groups of workers, together with efforts on the part of union leaders, State officials and enlightened employers to elaborate restrictive conciliation schemes and procedures for resolving disputes. ${ }^{8}$

Despite certain earlier prefigurations, it seems reasonable to regard this pattern as basically novel and unique to the era beginning in 1870 and ending in 1914. Underlying this new pattern of strikes was the advance of worker organization from a very modest position in 1870 - about a quarter million trade unionists were organized and affiliated to the Trades Union Congress in that year - to the level reached at the end of World War I, when the bulk of the manual workers, skilled and unskilled, were organized in trade unions whose strength exceeded eight millions. This massive achievement, which has yet to be properly appreciated, was accomplished by aggressive worker activity at the point of production. ${ }^{9}$

In this sense, the strike truly came into its own as workers' preferred form of action in the 1870's. To be sure, evidence of occasional strikes can be found much earlier than this, but these seem to have played a far less important role in the broad array of popular protest and collective action. ${ }^{10}$ Thus, while Charles Tilly makes a strong case for locating the birth of the modern "social movement" - with its tactics of mass mobilization, its national orientation and its aggressive demands - around the political agitations of 1828-32, he nevertheless finds little indication that strikes were considered a major tool for pressing grievances. ${ }^{11}$ Strikes, and the effort to build unions, obviously became more important during the 1830's, and the 1842 Chartist strike centered in Lancashire clearly represented a dawning

${ }^{8}$ See J. H. Porter, "Wage Bargaining under Conciliation Agreements, 1870-1914", in: Economic History Review, Second Series, XXIII (1970); R. Davidson, "Social Conflict and Social Administration: The Conciliation Act in British Industrial Relations", in: The Search for Wealth and Stability, ed. by T. C. Smout (London, 1979).

${ }^{9}$ For the most recent overview, see E. H. Hunt, British Labour History 1815-1914 (London, 1981).

${ }_{10}$ C. R. Dobson, Masters and Journeymen. A Prehistory of Industrial Relations 1717 1800 (London, 1980), esp. the appendix listing strikes; J. Rule, The Experience of Labour in Eighteenth-Century England (London, n.d.), pp. 147-93.

${ }^{11}$ Ch. Tilly, "Britain Creates the Social Movement", in: Social Conflict and the Political Order, op. cit. 
realization of the potential of working-class power at the workplace. And yet, these initiatives remained essentially inchoate: the organizations formed in the 1830's were beaten back, and the strike of 1842 would fail to bring tangible results. Chartism was and would remain essentially a political movement that, while drawing support from both old and new sections of the working people and adopting extremely novel strategies of mobilization, nonetheless spoke a language of popular radicalism inherited from the past. That language gave the Chartists an effective purchase on the political events of the 1830's in particular, but equipped them poorly for the new politics of the 1840 's, and even less well for the long-term tasks of building up working-class industrial and political capacity in the relatively stable environment of late-nineteenth- and early-twentieth-century Britain. ${ }^{12}$

Even the advances in tactics proved ephemeral, for there was little sign of a genuinely national social movement in Britain from 1848 to the mid 1860 's. This seems in part to have been due to the temporary withdrawal of the State from overt involvement in the details of local government or social life. The efforts to reform municipal government and poor-law administration that marked the 1830's abated, and the repeal of the Corn laws removed yet a further spur to political activity. Working people, it appears, turned towards the building up of stable unions and, even more, of institutions of self-protection - Friendly Societies, Co-operatives, and so on. They also managed to carve out for themselves a much larger sphere of local political activity, linked at times to the existing parties, but often marked by a certain autonomy and independence. ${ }^{13}$

It was upon these institutional gains that the agitation for political reform commenced again after 1865, culminating in the Second Reform Bill of

12 A. G. Rose, "The Plug Plot Riots of 1842 in Lancashire and Cheshire", in: Transactions of the Lancashire and Cheshire Antiquarian Society, LXVII (1957); The Chartist Experience, ed. by J. Epstein and D. Thompson (London, 1982); I. Prothero, "William Benbow and the Concept of the "General Strike"', in: Past \& Present, No 63 (1974); B. Brown, "Lancashire Chartism and the Mass Strike of 1842: The political economy of working-class contention" [Center for Research on Social Organization, University of Michigan, Working Paper 203] (1979); C. Calhoun, The Question of Class Struggle (Oxford, 1982).

${ }_{13}$ H. Perkin, The Origins of Modern English Society (London, 1969), pp. 380-407, T. Tholfsen, Working-Class Radicalism in Mid-Victorian England (London, 1976), D. Fraser, Urban Politics in Victorian England (Leicester, 1976), and P. Joyce, Work, Society and Politics (Brighton, 1980), provide useful information on the organization underpinnings of urban politics. On unions and strikes, see National Association for the Promotion of Social Science, Trades' Societies and Strikes (London, 1860); H. I. Dutton and J. E. King, Ten Per Cent and No Surrender (Cambridge, 1981); R. Price, Masters, Unions and Men (Cambridge, 1980); M. Holbrook-Jones, Supremacy and Subordination of Labour (London, 1982). 
1867. Indeed, the years $1867-70$, into which were compressed the second installation of suffrage reform, the formation of the modern Liberal Party with significant working-class support, and a major controversy over the status of unions and strikes, seem to have constituted a distinct rupture in patterns of collective action. Though the movement for reform involved many workers and their trade societies, it was conducted with the political tactics developed by the advocates of Catholic Emancipation in the 1820's and reformers of the early 1830 's, and refined by the Anti-Corn-Law League and the Chartists. Like the social movements of 1828-32, the reform agitation of 1865-67 did not much rely upon strikes as vehicles for mobilization, nor were industrial tactics seen as having much capacity either for influencing the authorities or for achieving much on their own. The movement surrounding the Second Reform Act was accompanied, however, by the last substantial outbreak of food riots in the South - in Deptford and Greenwich, as well as in more rural areas such as Oxford and Devon. As a form of collective action, the food riot was certainly not predominant, but it was nonetheless at least viable in the mid-Victorian era. In an incident that reads like something from the eighteenth century, 500 women in Durham were moved as late as 1872 "to parade through the streets with banners, fire-irons, shovels and trays, 'with which they continued to beat, making wild and unearthly music", protesting the cost of meat, milk and potatoes. The ostensible leader of the women threatened to burn in effigy any other woman who bought food at what were thought to be excessive prices. Community organization was strong enough, its "moral economy" meaningful enough, to make the threat effective, and the movement spread to other colliery villages in the County. ${ }^{14}$

Despite their occasional recurrence, most notably during the First World War, food riots did tend to disappear. Whether this reflected a maturation of protest is difficult to determine. One key factor seems to have been the decline in agricultural prices in the Great Depression, which reduced food costs by about 40 per cent from 1877 to 1896 . Even when prices began to rise again after 1905, the cost of food remained relatively stable, and thus came to constitute a smaller proportion of workers' expenditure than it had before. The effect, it appears, was to shift attention from consumption to wages and conditions of employment, and to re-locate protest from the market to the place of work.

14 D. C. Richter, "Public Order and Popular Disturbances in Great Britain, 1865-1914" (University of Maryland, Ph.D. thesis, 1965), pp. 30-31; R. Storch, "Popular Festivity, Social Protest and Public Order: The Devon Food Riots of 1867" (Pacific Coast Conference on British Studies Meeting, Los Angeles, April 1979). 
Though food riots became fewer, other types of riot continued to occur after 1870 , and quite a substantial number took place in urban, industrial centres. Still, the pattern was for the number of such outbreaks to decline, and for riots and strikes to become distinct, and ultimately antithetical, modes of action. (The exception, of course, was the continuation through 1914 of riots against the use of police and troops to protect blacklegs during strikes.) Thus, of 452 riots counted up between 1865 and 1914, 292 occurred in the quarter century ending in 1890 , and only 160 in the next twenty-five years - a decrease of over 40 per cent. More specifically, of the seventy-four situations in which riots were associated with strikes, fifty-six took place before 1895 , but only eighteen from then until 1914 . The gradual replacement of riots by strikes was noted explicitly by Thomas Brassey in the late 1860 's, and the change was most welcome: "The conduct of the trade unionists, while out on strike, will probably be as much superior to that of the rioters in the manufacturing districts in the early part of the present century as the discipline of the standing army is to that of the guerilla band." No doubt when George Potter claimed in 1871 that "instead of violence accompanying strikes as once it too often did, outrage of any kind is now the exception, and is so rare as to be scarcely that"', he had an interest that was more than historical, but his claim was only somewhat premature. $^{15}$

All this suggests that by 1870 British workers had become quite proficient in the waging of strikes in spite of sustained opposition from the articulate public, and persistent difficulties with the courts. The legal status of strikes and picketing remained precarious at least until 1906, and despite the reform of 1875 , but by the 1870 's unions were quite fluent with the law, and adept at tailoring their actions to suit its restrictions. And if the "public" were still predominantly hostile to strikes, there were some notable cases where they did support strikes, as in the engineers' strike of 1871 and the dockers in 1889 , and, perhaps more importantly, they came to accept the inevitability of strikes. The shift in the discourse about strikes is evident in many forums, but nowhere more obviously than among social scientists. The famous investigation of the National Association for the Promotion of Social Science in 1859 smacks of a sense of wonder, discovery and novelty; while Bevan's paper to the Royal Statistical Society is greeted with a chorus of arguments that have obviously been rehearsed many times over. Even

15 Richter, "Public Order and Popular Disturbances", pp. 85, 260; G. Potter, "Strikes and Lockouts from the Workman's Point of View", in: Contemporary Review, XV (1870), pp. 34-35, quoting Brassey; id., "Trades Unions, Strikes, and Lockouts. A Rejoinder", ibid., XVII (1871), p. 535. 
political economists were forced gradually to amend their arguments in the face of workers' sustained preference for behaviour that was economically "irrational". With justice, George Howell could assert in 1879 that "The right to strike is not [. . .] seriously disputed."16

\section{III}

Having thus "learned the rules of the game", British workers after 1870 took rapidly to organizing and to its necessary concomitant, strikes. Thomas Wright, the "Journeyman Engineer", perceived this essential thrust to working-class activity as early as 1871 .

Average English workmen are not so political as Continental, and especially French, workmen are. [...] They have not the type of mind for which theoretical or philosophical politics have fascination [. . .]. their political thoughts and aspirations, though they scarcely recognise them as being strictly political, turn exclusively upon improving the position of labour in relation to capital. And this they seek to accomplish by direct action - as, for instance, by strikes and the strengthening of trades-unions - and not by the establishment of entirely new social systems. ${ }^{17}$

The history of both unionism and strikes from 1870 through the war is concerned, therefore, with the spread of each downwards and outwards (and occasionally upwards) to progressively larger sections of the working class. This extension is revealed clearly in the statistics of strikes, of strikers and of trade-union members from 1870 through 1914. These data suggest the main outlines of the second set of questions to be addressed in this paper. First, organization among workers increased dramatically and consistently throughout the entire period. Strike activity also grew, in the sense that strike-propensity was higher across British industry at each successive

16 See W. H. Fraser, Trade Unions and Society (London, 1974), pp. 167-97, for a brief survey of the law regarding strikes; also J. Orth, "Striking Workmen before the Courts, 1859-71" (University of North Carolina, School of Law, unpublished paper, 1980); Trades' Societies and Strikes, op. cit. The comments on Bevan are in the Journal of the Royal Statistical Society, XLIII, pp. 55-64. On the public support for the Newcastle engineers, see J. Burnett, Nine Hours' Movement. A History of the Engineers Strike in Newcastle and Gateshead (Newcastle upon Tyne, 1872), and, more recently, E. Allen et al., The North-East Engineers' Strikes of 1871: The Nine Hours' League (Newcastle upon Tyne, 1971). On political economy, see also S. Pollard, "Trade Unions and the Labour Market, 1870-1914", in: Yorkshire Bulletin of Social and Economic Research, XVII (1965), which makes a rather pessimistic argument on the ability of unions to increase labor's share of national income. See also G. Howell, "Strikes: Their Cost and Results”, in: Fraser's Magazine, New Series, XX (1879), p. 767.

${ }_{17}$ "The Journeyman Engineer", "The English Working Classes and the Paris Commune", in: Fraser's Magazine, New Series, IV, p. 62. 
peak in the curves of strikes and strikers. But the most distinctive aspect of industrial conflict was its tendency to occur in sharp explosions about every other decade. The problem, then, is to explain both the overall and spectacular advance or organization and the way the three great strike waves of $1871-73,1889-90$ and 1911-13 fit into the process. Unfortunately, there has been surprisingly little attention paid by labor historians to either aspect of this problem.

This is not the place to review the reasons for labor historians' neglect of the problem, though that is an interesting topic in its own right. The intention is rather to begin to address the substantive issue. First, though, it is necessary to attend briefly to the formulation of the question. The norm for analysis in labor history has been to focus upon the accumulation of grievances, as if the relationship between the extent and character of oppression and the resistance to it was uniformly close and direct. By now, though, the sum of research on collective action showing the importance of strength and resources for mobilization ought to allow us to modify that approach considerably, so that the key question becomes not "Why did workers fight?", but rather "What allowed for or facilitated their translation of grievance into protest?' It is important, secondly, to recognize that, because the transformation in organization and strikes occurred throughout industry, the critical factors should themselves be effective at a broad societal level. What one is seeking, therefore, are changes that cut across industries and that combined to enhance the collective capacity of working men and women to organize and resist. Let us review briefly the nature of this increase in organization in order to discern its social origins.

Before 1870 , the social reach of unionism and of strikes was very narrow. Not without reason were unions in this period attacked as the province of the skilled and best-paid of workers. "It is notorious", one hostile observer wrote, "that strikes and combinations have been most common among those portions of the working population whose wages are highest." ${ }^{18} \mathrm{By}$ 1914 , this was no longer true in any sense: organization and strike-proneness had become common throughout the working class. The change is recorded in both the geography and the industrial distribution of strikes. In the 1870 's, medium-sized towns exhibited the highest strike rates: Barnsley came just after London in the list of strike locations; Manchester saw fewer than Dundee or Merthyr; Sunderland outpaced Birmingham, Bradford, Bristol and Belfast. A roughly similar pattern can be observed during the explosion of the "new unionism", despite the symbolic and psychological importance of the London dock strike. This reflected, it seems, the coming

18 Quoted in Potter, “A Rejoinder”, loc. cit., p. 529. 
to union organization of operatives in basic industry located in these urban centers of modest size. The pattern shifted slightly after 1900 , as many transport and service workers in the large provincial cities, and in London, finally succeeded in building stable unions and so were able to launch effective strikes. These geographical patterns were manifestations of the continued extension of organization, from the craftsmen in the largest cities to the operatives in the factory towns and the miners in their mining villages, then back to the relatively less skilled workers in the service industries of the big cities. ${ }^{19}$

The industrial distribution of strikes reflected the same process: surprisingly broad in 1871-73, it broadened still further in the years approaching 1914. The militancy of 1871-73 touched at its peak agricultural workers, dockers and other difficult-to-organize groups. Even among the engineers, the unorganized played a major role, as in Newcastle in 1871, when no more than 10 per cent of the strikers were ASE members. From then until 1914, strike-propensity was surprisingly evenly spread out in "the staple industries", as Bevan had noted for the 1870's. Though some groups, like the miners, were more prone to strike (for reasons that have been discussed many times over), the really marked divergence between industries visible since the 1920's was much less clear before 1914. And the changes that do occur before 1914 - the slight decline in strikes among builders, the increase among transport workers - confirm the tendency for the differences between industries and between skilled and unskilled to lessen somewhat as organization advanced. ${ }^{20}$

So while strikes broke out and organization deepened among the skilled, the truly novel phenomenon was the enrolment of those without craft skills into the labor movement, and it was this that accounted for the massive growth in unions and in strike activity throughout the pre-war era. Three sets of factors seem most compelling as explanations of this change. First, there was crude demography: the ranks of the "semi-skilled" and "unskilled" increased substantially after 1870 . This was intimately linked with a second factor: the nature of industrial development meant an increased demand for semi-skilled, as opposed to skilled, labor, and this demand was filled largely, though not exclusively, by an upgrading in the status of unskilled or casual labor. Third, there is evidence that the social ecology of mid-Victorian cities slowly gave way to a more socially segreg-

19 Bevan, "The Strikes of the Past Ten Years", loc. cit. , p. 45; L. H. Lees, "Strikes and the Urban Hierarchy in English Industrial Towns, 1842-1901”, in: Social Conflict and the Political Order.

${ }^{20}$ Bevan, "The Strikes of the Past Ten Years", pp. 39-42; Cronin, Industrial Conflict in Modern Britain, op. cit., pp. 159-61 and, on mining in particular, pp. 179-83. 
Table 2. Major participants in strikes, 1871-73

Industry of occupation

Number of strikes

Agricultural laborers

Bakers

Boilermakers

Bricklayers

Building operators

Carpenters and joiners

Colliers

$\begin{array}{lr}\text { Cotton hands } & 19\end{array}$

Dock laborers $\quad 15$

Engineers and fitters $\quad 37$

Flax, linen and jute hands $\quad 24$

Ironworkers 44

Masons $\quad 31$

Nail and chain makers $\quad 14$

Navvies $\quad 5$

Painters $\quad 8$

$\begin{array}{lr}\text { Plasterers } & 9\end{array}$

Plumbers $\quad 81$

Printers and compositors $\quad 10$

$\begin{array}{ll}\text { Quarrymen } & 16\end{array}$

Railway and telegraph employees $\quad 13$

Shipbuilders $\quad 28$

Shoe and boot makers $\quad 48$

Slaters $\quad 11$

Tailors $\quad 24$

All others $\quad 232$

Total 806

Source: Bevan, "The Strikes of the Past Ten Years”, pp. 39-41.

ated pattern of residence during the massive urban growth of 1870-1914. The effect was to create a physical space for the development of a strong and distinctive working-class culture sustained by, and itself helping to sustain, a broad array of social and political institutions that together added substantially to the resources which workers could mobilize on their own behalf. 
To document the extent and impact of these changes throughout the different industries and communities in which British workers labored and lived would require a great more space than is available here. It is nevertheless possible to state that each of these trends is documented extensively in the literature on labor and social change and that, when taken together and interpreted in terms of the balance of resources available to working people, they added up to a major change. At the point of production and in their communities, it seems, British workers found new sources of strength between 1870 and 1914. This was particularly important for those who did not possess a certified and marketable skill with which to bargain. In order for this set of changes in the underlying capacity of groups of workers to organize to eventuate in a wave of strikes and organizations, however, two additional conditions were necessary. The first was the long-term weakness of the employers and the positive predisposition of the State towards working-class organization. It is true that employers sought to match the workers' gains in strength by forming their own groups, but the fragmented structure of industry militated against successful employer combination. In most sectors of the economy firms were small, specialized and highly competitive. So while it was possible to put together a united front of employers for a brief confrontation with the unions, as happened in engineering in 1897-98, employers were unable to take advantage of their tactical victories to assert firm control at the workplace over the long run.

This weakness was compounded by the posture of the State. No doubt there were instances when the State intervened on the side of the employers and, as the Taff Vale decision amply demonstrated, the courts were capable of being used against unions as well during the 1890's and early 1900's. But most of the time the government preferred to mediate and conciliate, rather than to repress, and after 1906 its influence ordinarily favored the formation of stable organizations of workers and employers. With the coming of war in 1914, this tendency would be still further accentuated, and the State would end up virtually sponsoring greater organization on both sides of industry. The employers' rather feeble efforts to resist unionization therefore lacked the extra crucial dimension of state leverage, and overall the balance of advantage swung to the workers. ${ }^{21}$

The second factor was a favorable economic conjuncture. If secular trends in the evolution of economy and society lay behind the great changes

21 On these two issues, see W. R. Garside and H. F. Gospel, "Employers and Managers: Their Organizational Structure and Changing Industrial Strategies", in: A History of British Industrial Relations 1875-1914, op. cit.; Ch. Wrigley, "The Government and Industrial Relations", ibid. 
in industrial relations, it is nonetheless the case that the pace of development varied considerably from year to year. Both the growth of organization and the outbursts of strikes were concentrated in three "great leaps", in 1871-73, 1889-90 and 1911-13. What caused this distinctive clustering of forward movements? The vagaries of the trade cycle are no doubt part of the answer: each of the strike waves occurred when the labor market was most favorable to workers. The wild boom of 1871-73 saw unemployment in the organized trades well below 2 per cent; in the same industries only 2.1 per cent were out of work in $1889-90$, compared with 10.2 per cent just two years before; in 1911-13, unemployment averaged just under 3 per cent, whereas double that were out of a job in 1908-09. Clearly, a favorable labor market was something of a precondition for launching a wave of militancy. ${ }^{22}$

A slightly broader view of economic conjuncture suggests a further feature common to these moments of insurgency. If one considers not simply the classic trade cycle of 7 to 10 years, but also the long waves of roughly half a century through which capitalist development seems to pass and progress, it becomes clear that strikes and organization have tended to come during short-term upswings near the end of each phase of the long wave. The first great British strike wave in 1871-73 came during the speculative climax of the mid-Victorian boom; the new unionism broke through during the flurry of trade just before the last trough of the Great Depression; and the "labor unrest" swept Britain near the end of the long Edwardian prosperity. This quite marked pattern suggests a very intimate relation between the lange Wellen der Konjunktur, as Kondratiev called them, and labor militancy. It seems, in addition, that long waves were connected in important ways with the structural evolution of economy and society which brought about the enhanced capacity for workers' collective action after $1870 .{ }^{23}$

\section{IV}

Perhaps the best way to show these links and mediations, and how they fit into the broader movement for organization, is to describe briefly the most salient features of each of these major outbreaks of strikes and organization. Unfortunately, one must begin with what is surely the least well

22 These statistics were taken originally from the Department of Employment and Productivity, British Labour Statistics: Historical Abstract, 1868-1968 (London, 1971). They also appear, together with extensive strike statistics, in Cronin, Industrial Conflict in Britain, pp. 206-38.

23 J. E. Cronin, "Stages, Cycles, and Insurgencies: The Economics of Unrest", in: Processes of the World System, ed. by T. K. Hopkins and I. Wallerstein (London, 1980). 
documented of such episodes, the militancy of 1871-73. According to George Bevan's count, the number of separate strikes increased from a mere 30 in 1870 to about 150 for 1872 and 1873, an increase of well over ten times. Of these, however, very few find their way into George Howell's list of "Great Strikes" or a similar list compiled by the Board of Trade in 1889, so our knowledge of most remains scanty indeed. The best-known is the engineers' nine-hour strike on the North-East in 1871, which seems to have been a stimulant to other workers. Several features stand out in the varied accounts of that struggle: the quality of the men's leadership, particularly John Burnett; the fact that most of the strikers were not members of the union; the recalcitrance of the owners and the public support generated by the workers. The demand for a shorter working day was extremely popular, and was widely emulated by workers in other industries. The initiative of the unorganized was also characteristic of the movement elsewhere, and the two often came together, as when "a massive strike wave" swept Sheffield in 1872, bringing over 1,200 smelters into the union around the demand for a shorter week. The strikes in general reflected a broad attempt to organize unions, so much so that membership in TUC-affiliated societies grew from about a quarter of a million in 1870 to almost 1.2 million in 1874 . The growth was particularly concentrated in heavy industry, like engineering and metal working: the ironworkers grew from a mere 476 members in January 1869 to over 35,000 in $1874 . .^{24}$

Unions and strikes, though still strongest in the older, skilled trades, were clearly spreading into basic industry (see Table 2). Unskilled "boys" in shipbuilding, gas stokers, building laborers, dockers, even agricultural laborers, formed unions and/or struck in the early 1870's in what was by then the furthest extension of organization ever achieved. In 1874, for example, the National Union of Agricultural Workers claimed 100,000 members in approximately 1,000 branches. Among the miners, it was the South Wales coalfield, which was newer than other fields, rapidly expanding and previously less well organized, that was the center of mining militancy. Generally, the strikes of 1871-73, whether in manufacturing or

${ }^{24}$ See Table 1 for details, as well as Bevan, "The Strikes of the Past Ten Years"; Howell, "Great Strikes", loc. cit.; Report on Strikes and Lockouts in 1888. On the iron and steel workers, see N. P. Howard, "Cooling the Heat: A History of the Rise of Trade Unionism in the South Yorkshire Iron and Steel Industry, from the Origins to the First World War", in: Essays in the Economic and Social History of South Yorkshire, ed. by S. Pollard and C. Holmes (Barnsley, 1976). 
the older trades, were short, small and successful, pushing organization to what were then its furthest possible limits. ${ }^{25}$

Inevitably, the depression of the late 1870's destroyed much of what was gained by 1874 . Union membership was halved, but still remained almost twice as high as it had been in 1870 . The footholds of unionism in agriculture, on the docks and among other unskilled workers were lost, but advances made within industry were more stable. Overall, therefore, this foray into organizing beyond the skilled trades produced mixed results. One obvious weakness, it seems, was ideological and strategic. Specifically, the extension of organization downward and outward within the working class was not accompanied by a new set of political ideas, by any novel strategic thinking, or by anything that could serve as a new philosophy to guide and inspire labor. Yet clearly the outlook and style inherited from the established unions were not well suited to the needs of the mass of workers.

The inability to maintain the gains of 1871-73 showed the inadequacy of the old unions and the old ideas for the new era of mass organization. In this sense, the subsequent Great Depression was a great teacher of labor. The defeats of 1878 in particular prompted changes in the cotton unions, the continuous fall in product prices gradually disabused the miners and others of the fondness for sliding scales, the railwaymen slowly discovered the need for an "all grades" strategy, even the engineers toyed repeatedly (if unsuccessfully) with plans for opening membership more broadly, and, most obviously, a new generation of activists came to the conclusion that a broad, inclusive strategy was the key to organizing the unskilled. These ideas and this strategic perspective crystallized in the new-unionist explosion of 1889 , but the antecedents go back to the 1870 's. It is no doubt true, as Howell wrote in 1902, that very quickly the novelty of the new unionism wore off, that the new unions took on characteristics of the old and vice versa, but the net effect of the movement was nevertheless a major shift in the nature of the labor movement. ${ }^{26}$

2s On shipbuilding, see J. F. Clarke, "Workers in the Tyneside Shipyeards in the Nineteenth Century", in: Essays in Tyneside Labour History, ed. by N. McCord (Newcastle upon Tyne, 1977); on agricultural workers, see Howell, "Great Strikes", pp. 301-03; R. Groves, Sharpen the Sickle! The History of the Farm Workers' Union (London, 1949), pp. 39-92.

${ }_{26}$ G. Howell, Labour Legislation, Labour Movements, and Labour Leaders (London, 1902). More generally, see Hunt, British Labour History, op. cit., pp. 304-15, where the contrast between the new unionism and the old is reviewed. Hunt generally opts for the "revisionist" perspective, which minimizes the difference between the two, but the evidence he marshals nevertheless makes clear that the labor movement was very different after 1889 than before. 
Once again, in 1889-90, union membership jumped: from 817,000 in 1888 to $1,470,000$ in 1890 ; the number of strikes increased a comparable amount, from 517 in 1888 to 1,211 in 1889 and just over one thousand in 1890; while the workers involved grew by still more, from 119,000 in 1888 to just under 400,000 in 1890 . As in $1871-73$, strikes were relatively short and extremely successful. In 1889-90, 312,000 workers achieved clear-cut victories in strikes, a further 254,000 some sort of compromise, while only 143,000 experienced defeat. This is quite a remarkable record, for it is a commonplace in industrial relations that neither side is ordinarily anxious to claim or concede victory or defeat. The industrial spread of strikes was even broader than in 1871-73, with much increased participation by transport workers and by workers in metal, engineering and shipbuilding, and somewhat reduced activity among the mostly skilled building trades. The shift toward heavy industry and toward the less skilled was thus further accentuated. Most significantly, the 1890 's witnessed the first large-scale organization of women workers, mostly in textiles, but also in teaching and other white-collar occupations. ${ }^{27}$

Predictably enough, the wave of $1889-90$ was followed by an employers' counter-attack, which began during the depression of 1892-93 and continued through the decade. The reaction was notable in several respects. First, it led to some of the most bitter, and occasionally violent, confrontations in the history of labor, among dockers, miners, engineers, quarrymen, boot- and shoemakers, and others. Second, the employers' side took the initiative in evolving new forms of organization with which to prosecute their aims. The Shipping Federation and the Engineering Employers gave the lead in organized strikebreaking, while individual companies pursued the legal attack on unions that culminated in Taff Vale. The advance in workers' organization thus prompted counter-organization among employers, which tipped the balance of forces back in their direction. Third, despite the strength of the attack upon labor, union membership remained relatively stable through the 1890 's and even began to creep up again after 1896. This was no doubt due to the much improved labor market in the late 1890's, but, whatever the cause, it meant that unions kept more of the gains resulting from the new unionism than they had from 1871-73 strike wave. The mass organization of industry was gradually taking hold..$^{28}$

27 See S. Lewenhak, Women and Trades Unions (London, 1977); Hunt, British Labour History, pp. 299-300.

28 See E. Wigham, The Power to Manage (London, 1973), pp. 29-62, on the Engineering Employers' Federation; J. Saville, "Trade Unions and Free Labour: The Background of the Taff Vale Decision", in: Essays in Labour History, ed. by A. Briggs and J. Saville (London, 1960), more generally. 
The further development of unions and strikes was greatly hindered after 1900 by the combined effects of legal restrictions, which lasted until 1906, strong employer organizations, and a very uncertain economic climate. The underlying structural weakness of the British economy meant that the upswing beginning of 1896 was much weaker than in other countries, and unemployment from 1901-10 was on average double that of 1896-1900. The numbers unemployed were below three per cent during 1898-1900, but consistently above that every year after until the war. Faced with such disadvantages, union strength stagnated, and even declined slightly, from 1900 until 1905 . The legislation of 1906 , and a reasonably strong demand for labor, allowed a jump in that year, but membership declined again from 1907-9. By 1910 , membership had crept over the $2 \frac{1}{2} 2$-million mark, from which point a rapid rise ensued. Over a million and a half new members were added during the next three years, as organization was consolidated and extended among transport workers - dockers and railwaymen primarily - and in basic industry.

The "labor unrest" of 1911-13 was thus, in the first instance, a great qualitative breakthrough in the extent of organization; and it was achieved in the teeth of sustained employer opposition. Inevitably, such a movement had to be led by the rank and file, and often even took the form of a rebellion against the union leaders. Not without reason did Sydney Buxton, President of the Board of Trade, complain in 1911 about "the serious diminution in the control which the leaders of the men used to exercise over their rank and file". It was also left to the rank and file, and to various militants, to articulate a new philosophy of mass unionism and direct action. Whether a great many workers grasped the key tenets of Syndicalism or not, the Syndicalist approach resonated well with the mood of the men and helped to express its essential thrust. The rebellion within the labor movement against the leaders can in a sense be viewed as the critical, preliminary skirmish in the struggle for another, qualitative advance of organization. ${ }^{29}$

The nature of strikes during 1911-13 reinforces this analysis. The spread of unions and of the capacity to strike is revealed in the mass character of disputes and in their industrial incidence. The size of the average strike

${ }^{29} \mathrm{Ch}$. Wrigley, The Government and Industrial Relations in Britain 1910-1921 (Loughborough, 1979), p. 5, quoting Buxton. On rank-and-file movements and Syndicalism, see B. Holton, British Syndicalism, 1900-1914 (London, 1976), and Price, Masters, Unions and Men, op. cit., pp. 238-67. For the view that the unrest was a matter of the trade cycle and little else, see H. Pelling, "The Labour Unrest, 1911-1914", in Popular Politics and Society in Late Victorian Britain (London, 1968). See also E. H. Ph. Brown, The Growth of British Industrial Relations, 1906-1914 (London, 1959). 
increased from 350 during $1889-92$ to 780 workers during 1910-13. As in $1889-90$, these strikes were immensely successful, $1,135,000$ strikers ( 44 per cent) winning outright victories against employers, $1,080,000$ ( 42 per cent) being involved in compromises, and only 363,000 (14 per cent) experiencing clear-cut defeats. The pattern of participation revealed a further shift away from skilled craftsmen towards the newer, more "proletarian" workers in industry and transport, with miners, dockers, railwaymen and textile workers especially prominent. ${ }^{30}$

The transformation wrought by these waves or organizing and strikes by 1914 is perhaps best revealed by the changed role and attitude of the government. The government had become interested in fostering industrial peace in the late 1880's, appointing the Royal Commission on Labour of 1889-92, setting up a Labour Department of the Board of Trade just after this, intervening in the 1893 coal dispute, and actively fostering conciliation from 1896 onward. Faced with employer resistance and not pressed on by any crisis in industrial relations, such efforts languished from about 1897 to 1910. The wave of strikes that broke out in 1911, however, brought government back into the field for good. Troops were sent to Wales in 1910, to Liverpool and other ports in 1911; Lloyd George became involved directly in 1911-12 with the railwaymen and the miners; and throughout the turbulence the government's chief conciliator, George Askwith, was kept continually busy. The net effect of government intervention was problematic - on the one hand, its protection of blacklegs angered workers and assisted employers, while, on the other, Lloyd George's efforts to mediate were resented almost as much by the employers. By 1913, in fact, the government was disillusioned with the results of its efforts, and the outcome of the contests on the docks and the railways remained in doubt, the possibility of major disputes in 1914-15 looming just over the horizon. It is especially unclear just what role government would have played in such confrontations, but it seems unlikely they would have been able to withdraw. By 1914, workers were organized in some fashion in all the major industries, and their combined action could have dramatic consequences. Government could no longer remain aloof from the day-to-day conduct of industrial relations, and they no longer did.

\section{V}

With the coming of the Great War, the government's role would become even more significant, perhaps even decisive. Before describing the effects

30 The general pattern of strikes is most clearly indicated in G. R. Askwith, Industrial Problems and Disputes (London, 1920). 
of the war upon industrial relations, however, it might be useful briefly to recapitulate the relationship between strikes and organization prior to 1914. Judged by their timing, location and strategic orientation, the successive strike waves of $1871-73,1889-90$ and $1911-13$ are best understood as component parts of a long struggle to organize British industry. In each case, of course, the strike movement achieved a certain degree of inertia and momentum, but this was limited in scope and, it seems, subordinate to the overriding aim among workers to establish some collective power and organization at the workplace.

A clear indication of this is the statistical relation between the magnitude of strike waves and the scope of union-organizing efforts. The peak of strikes in each of the three explosions of militancy was slightly higher than the previous one, but only slightly. The peaks of strikers were higher, but were not sustained. The peaks of unionization, however, were much higher and they persisted. This suggests a relation that was not reciprocal: strike movements built unions, but unions did not overall do a great deal to increase strike-propensity. ${ }^{31}$ Many possible reasons can be adduced for this asymmetrical relationship, but whatever the explanation, the reality was that the gradually increasing capacity of working people to organize, which was reflected in increasing unionization, was not reflected in as broad a resistance at the workplace as might have been possible.

The major effect of the war on industrial relations seems to have been to change this and to stimulate a much more aggressive consciousness and pattern of activity among the bulk of the working class. In this sense, the war brought about a major discontinuity in the long-term pattern of strikes. Most important, the new militancy was both broader than ever before, and it was sustained for a surprising period of time - until, in fact, the defeat of the General Strike in 1926. Even when the bottom fell out of the post-war boom in late 1920 , workers continued to strike; and it took several more years to restore "order" in the industrial-relations system. This process has been described in some detail elsewhere, for present purposes two simple pieces of evidence can be noted.

Prior to the Great War, the most massive outburst of strikes occurred in 1912 , when over 1.2 million workers participated. But of that large number,

31 Thus, if one calculates the ratio of the number of trade unionists (in thousands) to the peak number of strikes during strike waves, one gets the following pattern of dramatic decline: $1873-73-1.01 ; 1889-90-0.77 ; 1911-13-0.36$. No doubt part of the drop reflects underlying shifts in the organization of industry, and a further part the spread of organization from craft to semi- and unskilled occupations and the attendant sectoral differences entailed in that, but a portion of the change must certainly be attributed to a genuine relationship between organization and strikes. 
a full three-quarters were miners. By 1919 , the year of the greatest post-war participation, only a bit over a third of the 2.4 million strikers were miners. Truly massive numbers of other workers took part in the labor upheavals after the war. And they did so without the stimulus of early victories that had helped to spread the earlier strike waves. From 1918 through 1922, the great majority of the strikers were engaged in struggles with mixed outcomes; even in 1919 approximately 60 per cent could win only some sort of compromise, and in none of these years did those who won strikes outright outnumber those who lost outright. Nevertheless, the very ability to win compromises in the depressed years of 1920,1921 and 1922 represented an impressive resilience, as did, of course, the revival of militancy in 1925 and 1926.

In this context, the defeat of the General Strike in 1926 takes on quite serious proportions. There has been a tendency among labor historians and industrial-relations specialists to see the General Strike as merely anticlimax, as a relatively meaningless gesture of solidarity without lasting impact upon the position of labor in British society. It is possible to argue instead, both from the statistical evidence on strikes and from a reading of the broader context, that it was an absolutely critical moment in the construction of the post-war social order. Even if the British government was wrong in construing the contest as a battle over the constitution, it certainly was a battle over whose interests were to dominate in the industrial and social policy of the next two decades. That there had to be such a test in order to re-establish stability, that it was so long in coming and that its outcome was so unpredictable, all testify to the qualitatively different dimensions of the labor insurgency of the era after the war. ${ }^{32}$

It would be much beyond the scope of this paper to attempt a comprehensive explanation of the origins of this new militancy. ${ }^{33}$ The aim here has been primarily to point it out. One may conclude, however, by discussing two possible answers to the problem of origins. One possibility is that there is, or was, a certain threshold of working-class organizational strength, before which struggle is largely defensive and incapable of shifting the overall balance of social power, but beyond which the power of the workers

${ }^{32}$ See, for example, G. A. Phillips, The General Strike (London, 1976). A view much closer to that expressed here is contained in $\mathrm{H}$. Ph. Brown, The Origins of Trade Union Power (Oxford, 1983), pp. 68-88.

33 The beginnings of such an interpretation are presented in my "Labour Insurgency and Class Formation: Comparative Perspectives on the Crisis of 1917-20 in Europe", in: Work, Community, and Power. The Experience of Labor in Europe and America, 19001925 , ed. by J. E. Cronin and C. Sirianni (Philadelphia, 1983). 
becomes a much more distinct threat to the prevailing social order, and that such a threshold was crossed in Britain during the war. The second possibility is that the war itself was the key factor in transforming strikes, both because of the edge it put upon workers' grievances and because of its politicizing effects. And perhaps the most satisfying explanation will be found by combining these two notions, and recognizing that the period of the war simultaneously strengthened workers enormously, angered them bitterly and forced them to interpret their problems politically. 